\title{
THE SOCIAL IMPACT BOND AS A FINANCIAL INSTRUMENT
}

\author{
Marcin Wiśniewski \\ Poznań University of Economics and Business, Poznań, Poland \\ e-mail: marcin.wisniewski@ue.poznan.pl
}

ORCID: 0000-0003-4609-6143

C) 2018 Marcin Wiśniewski

This is an open access article distributed under the Creative Commons Attribution-NonCommercial-NoDerivs license (http://creativecommons.org/licenses/by-nc-nd/3.0/)

DOI: 10.15611/fins.2018.4.07

JEL Classification: G18, G23, H40, K22, O35

\begin{abstract}
Social impact bonds are an innovative mechanism for financing social tasks with the financial resources of private investors. The repayment of the capital invested and capital gains depends on obtaining a predetermined social aim that is paid for by the public side under the "payment for results" formula. The previous work on this mechanism focused mainly on its task and organizational dimension. In this paper, the author attempts to define the social impact bond as a financial instrument. In particular, the financial side of the mechanism is considered. First, an attempt is made to determine the place of the social impact bond in the theoretical classifications of financial instruments. Second, the place of the instrument is indicated in the system of financial law. Finally, some remarks are made on the need to have the new instrument regulated in Polish legislation.
\end{abstract}

Keywords: social impact bonds, financial instruments, bonds, public management.

\section{Introduction}

The completion of public tasks by the state and local government require securing sources of funding. Both the tasks themselves along with the forms and sources of covering expenditure have evolved over time. In the financing of public tasks there has been an increased emphasis on raising the effectiveness of spending public resources. This process reflects the concept in the new public management approach characterised by the formula known as payment for results. Under the formula, public resources can only be spent on condition of meeting a set goal, usually in the form of completing another stage of a public task. Such a mechanism is meant to assure the effectiveness of public spending and boost the willingness of other sectors (private and non-governmental) to participate in completing public tasks - including their financial contributions and taking the risk of failure in the actions taken. 
In many countries, including Poland, one of the most important and interesting forms of such a method of payment is the implementation of the so called social impact bonds. In brief, this concept is an organizational-financial mechanism under which a non-public institution makes an intervention in a specific social area, the result of which is social effects that beat those that would have been achieved using traditional (budget) ways of financing. The task is commissioned by the public side which will pay out only on completing the project. In order to obtain financial resources towards project realization, the contractor (intermediary/executor) launches a bonds issue. Under this formula, this is the way in which investors provide their capital. The mechanism is conditional - the public side will only pay out on completing the task, thanks to which the capital investors can make a return along with due interest. On the contrary - if the project turns out to be a failure, in most cases the investors do not earn anything or even lose their capital. A mechanism like this requires effective construction as it needs to be attractive for all the parties involved.

The mechanism in question has already been analysed from the viewpoint of state policies, social policies and the public finance policy in particular, including the effectiveness and validity of financing public tasks with this instrument. However, so far, no classification of the new mechanism has been made in terms of the financial market and its instruments. An attempt to define the mechanism in a financial context and classify it as a financial instrument will constitute the first goal of this paper.

Despite the fact that the very name of the mechanism - a social impact bond implies financing by means of debt security, so far no issue of bonds (to the best of author's knowledge) has taken place. Typically, standard civil law agreements are applied instead. They describe in detail the dependencies between the investor and the intermediary, and between the intermediary and the public side (the commissioning party). In this paper, the author considers the possibility of implementing the mechanism in question by means of issuing bonds within the regulations of the Polish financial law, which constitutes the second goal of this paper.

\section{Social impact bonds - origin, definition, application}

As mentioned before, the mechanism of social impact bonds derives from the concept of new public management, i.e. the idea of financing public tasks on the "payment for results" basis. New Public Management (NPM) is a doctrine of public management administration which means a departure from administering (the bureaucratic model) to managing that relies on the economic evaluation of effectiveness with the application of market mechanisms (the managerial model). The NMP concept emerged for the first time in the Anglo-Saxon countries in the 1980s in response to the economic crisis of the previous decade and the increased significance of the services market and consumers' expectations about the quality of the services [Marchewka-Bartkowiak 2014, p. 1]. 
The reforms implemented on the basis of NPM are aimed at overcoming the "failures of the welfare state" and the "failures of public administration" through increasing thriftiness, efficiency and the effectiveness of the actions by the public sector, and through an increase in the quality of the services [Rajca 2009, p. 73]. The doctrinal components of NPM include: direct and professional public sector management, measuring the quality of the performed work by certain standards, more emphasis put on performance evaluation, desegregation of public sector units, boosting competitiveness in the public sector, implementing management styles known in the public sector, and increasing discipline and thriftiness in using public resources [Czarnecki 2011, p. 13].

The postulates of NPM include "focus on results" which can be defined as "a philosophy of taking actions where the process of meeting the goal is not as important as its result or effect." This postulate can be met by means of properly drawing up contracts that describe precisely the anticipated results. In this way the public sector unit shows that it attaches great importance to the value obtained with specified financial resources [Zawicki 2007, p. 155].

The "payment for results" concept that emerges from the abovementioned trend aims at minimising the costs incurred by the state while maximising the quality of the services offered. The emergence of the name of the concept dates back to the mid1800 s, and is associated with a solution applied in English schools. The mechanism linked the financing of a school to the results of the exams taken by its students. Finally, due to the teaching staff's dissatisfaction, the idea was ditched in 1890. The concept was brought back to life in Great Britain in the early 1990s. The mechanism was also implemented in the public health sector. As a result, the waiting time to see a doctor and commence treatment was significantly shortened [O'Connor, Neumann 2006, pp. 226-231]. The British health service discarded the system of contracting services in favour of the "payment for results" mechanism which resulted in the increased utilization of the available resources of the health service, not only those covered by previous contracts [Department of Health 2012, pp. 48-49].

The realization of a public task under the "payment for results" formula can concern any type of programme where payment is made at the closing stage after meeting certain goals, as opposed to the traditional approach where the transfer of resources is made before the project even commences. The formula requires determining the amount of payment for the result, the recipient of the payment, clarifying the type of result for which the payment is to be made. Such a solution also results in transferring the risk of project failure from the commissioner onto the executor of the programme [Department for International Development 2014]. Moreover, this solution makes it possible for the institutions commissioning a social task and those interested in the results (governments, local governments, and, ultimately, the citizens) to make contact with the project contractor. The key is the possibility to focus on rewarding tangible effects only, which replaces the idea of traditional contracts and grants. Past experience shows that this formula attracts 
all the entities previously not showing any interest in social tasks, which facilitates coming up with new business models and innovative solutions [Eggers, Macmillan 2014, pp. 227-228].

An indisputable advantage of the "payment for results" formula is the possibility of rationalising public expenditure, however the formula is not completely flawless. There is the issue of indexing social effects which are often immeasurable [Cooper et al. 2016, p. 65]. Another threat is the possibility to "dehumanise" the actions that are aimed at meeting the target at any cost [Larsson 2016]. This mechanism may result in so-called "creaming", i.e. giving up complex social issues in favour of more effortless interventions, the effects of which are achieved quickly and easily. Yet another issue is the risk of too much centralization in managing programmes and the risk of administration costs exceeding the earnings, particularly in the case of complex projects or projects of little social impact [PWC 2014, p. 4].

One of the mechanisms that take advantage of the "payment for results" formula is social impact bonds. Under this instrument, the payer, typically a government, local government or a public agency, undertakes to pay for the measurable effects of a social intervention. The prospect of making a return is meant to encourage private entities (but not only private ones) to invest their sought-after resources [Aylott et al. 2011, p. 5]. Investors provide the financial resources needed to fund certain services or social programmes and expect return payments of their capital and interest when their intervention achieves the social effect as originally defined. Cash flows can be made directly between the investors, the commissioner (the public side) and the project contractors. However, the funding structure most often also includes an intermediary in the form of a special purpose vehicle (SPV) that links all the sides of the mechanism by means of contracts [Griffiths, Meinicke 2014, p. 7]. The intermediary receives an intervention order from the public side, raises funds from investors, finances the actions of the contractor and, in the face of the project's success, settles the payment for the result by providing the investors with the return payment of their capital. Another significant role is also played by the evaluator, i.e. an independent entity that evaluates whether the particular social intervention is successful, and thereby decides if the commissioner remunerates the intermediary who, in turn, remunerates the investor. The links between the parties of the mechanism of social impact bonds are shown in Figure 1.

The first, and pilot programme using social impact bonds was a rehabilitation project at Peterborough prison in 2010. Since then, 26 financial interventions have been completed using the mechanism in question, and at the time of work on this paper (November 2017) another 78 projects were under way, and more than 30 had entered the design stage. The scope of the financial activities involving social impact bonds is broad - from rehabilitation, homelessness and unemployment to the education of the youngest citizens. Most projects concern enhancing access to the labour market for those affected by prolonged unemployment. The biggest project in terms of most funds invested is an assistance programme addressing mothers and their children in North Carolina [Instiglio 2017]. 


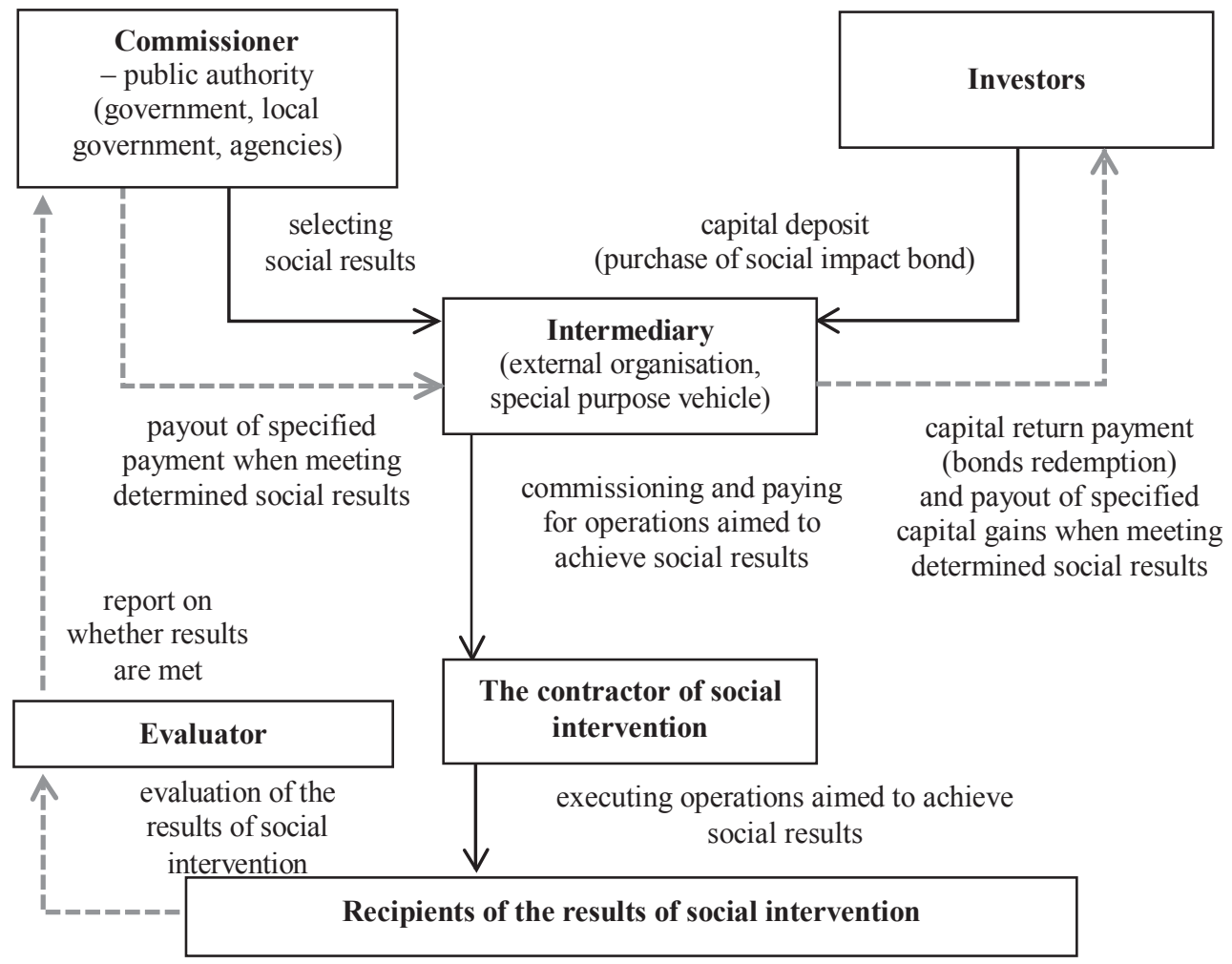

Fig. 1. The mechanism of financing public tasks with social impact bonds

Source: author's own work on the basis of [Marchewka-Bartkowiak, Wiśniewski 2015, p. 211].

Social impact bonds are to be applied in Poland, too. In 2016, the Ministry of Development launched a contest to select the best projects to be run under the formula. Currently the best ideas have entered the design stage, and they will be implemented after 2018 [Ministerstwo Rozwoju 2016].

\section{The social impact bond as a financial instrument - a theoretical approach}

In the previous chapter, the social impact bond was defined as a specific mechanism for financing public tasks, with a focus on the task and organisational aspects. Thus the financial aspect of this mechanism proves that the social impact bond can also be defined as a financial instrument. Hence it is the intermediary's undertaking to return to the investor the capital borrowed along with the due (often above the average) income on condition that the project has achieved the anticipated social result. 
Pro-social activities are financed by investors, and their success will be rewarded financially by the commissioner, i.e. the public side. Therefore, from the investor's point of view, it is due payout which is dependent on the success of the social intervention conducted by the intermediary and financed with the capital provided by the investor. The aim of our further considerations will be to classify the social impact bond amongst financial instruments, in particular by comparing it to other instruments with similar features.

Without doubt, social impact bonds are indeed a financial instrument. By referring to even basic definitions [Jajuga, Jajuga 2011, p. 21], it can be clearly stated that the social impact bond is a contract which defines the liabilities of the parties involved. The nature of those liabilities is not at all obvious because even though the instrument is called a bond, in light of the current law, e.g. in Poland, it is not completely certain if it really is. The social bond is not defined expressis verbis in the legislation on financial instruments - either in Poland, or, to the best of the author's knowledge, in any other country.

The solutions implemented around the world so far show that despite its name the social impact bond is not a bond in the sense of the legislation covering the issuance of and trading in securities, as in the case of a "standard" bond. Under the formula in question, the financial resources raised to finance social interventions are usually transferred after signing civil law contracts which define the rights and commitments of the parties. It is worth noting that the word bond has a double meaning in English, i.e. it may refer to a financial instrument, but it also signifies a type of close tie or an agreement with legal force. This, however, does not mean that the social impact bond could not be a security, which shall be discussed later.

When trying to classify social impact bonds among other financial instruments, it is necessary to look at their key features:

- debt character - a bond obliges the intermediary to return the capital and capital gains to the investor,

- conditionality - return payment of capital and income is conditional on the success of the social intervention,

- private nature - raising capital from investors typically takes place in the nonpublic market, and investment proposals are addressed at a closed and preselected group of investors.

The literature offers a number of classifications of financial instruments according to a variety of criteria. For the purposes of this paper, it is advisable to focus on the criterion concerning the rights which the instrument offers to its owner [Dębski 2007, pp. 16-17]:

- the right to the co-ownership of the asset,

- the right to specific interest or any other benefits,

- the right to obtain specific assets or a financial settlement in the future.

The criteria of rights comprised within the financial instrument allow for distinguishing the following instruments: 
- $\quad$ equity - incorporating the ownership right of the issuer's assets,

- debt - confirming the debtor's undertaking to return a specified amount of debt to the creditor,

- derivative - allowing specified cash flows in the future, linked to the price of the specified base instrument.

In light of the adopted classification, the social impact bond cannot be called an equity instrument, it is more of a debt instrument and derivative. Hence the social impact bond must be considered a separate type of financial instrument that has a lot in common with typical debt instruments - with bonds in the first place, but also, due to its conditionality, with derivatives such as options. The construction of social impact bonds - putting together bond and option features - also resembles structured products. The similarities shall be described in detail below.

The social impact bond as a debt instrument comprises the undertaking of its issuer (the intermediary) to pay out to its owner (investor) the invested nominal value plus capital gains, typically in the form of interest. By transferring the financial resources the investor turns the intermediary into their owner - like in the case of bonds or a loan - rather than a holder - like in the case of credit. Hence the social impact bond can be a bond, with the proviso that its buyout and financial benefits, as secured by the issuer, are conditional.

A comparison of a social impact bond to a straight bond reveals a number of differences [Costa et al. 2012, p. 5]:

- in most cases, straight bonds guarantee unconditionally the repayment of capital with due interest (fixed, variable or indexed); in terms of social impact bonds, payment is conditional on achieving the result of the intervention that they finance (this concerns both interest and the principal),

- $\quad$ social impact bonds, unlike straight bonds, usually cannot be resold (trading in them on the secondary market is not possible),

- social impact bonds carry with them more risk than straight bonds as, by assumption, the repayment of capital and the amount of interest is provisional on the results achieved.

The most important and arguable feature of social impact bonds is their conditionality. Basically, the commitments which the straight bond imposes are unconditional. An exception to this rule is the participation bond which entitles its owner to a share in gains on a par with the ordinary shareholder. Obviously, a dividend will only be paid out in the case of making a return. On the whole, however, conditionality is characteristic for derivatives such as options. The buyer of an option buys the right to make a decision about realizing the contract, and in due time he or she decides whether to use the right. Naturally, the buyer will only use the right if the relationship between strike price and market price is to his or her advantage i.e. the decision depends on gaining a benefit, and it is for this right that the buyer pays the issuer a certain premium. As far as the social impact bond is concerned it seems that the roles are reversed; it is not the investor but the issuer, or the commissioner of the 
task based on the evaluator's opinion, who decides whether to make payment. While in the case of the standard option the reward for the right to decide about realizing the contract (payment) is premium, with the social impact bond the premium only takes the form of the satisfaction of having performed a good deed. Without doubt, this type of bonus can also take a material form as the mere fact of getting involved in a social project enhances the investor's image as a "socially responsible" business. To conclude, in their construction, social impact bonds resemble the reversed option contract where the issuer of the conditional instrument decides about payment, and the investor, apart from capital return and possible interest gains, earns a "moral premium" for realizing a socially responsible investment.

The combination of the features of the debt instrument and option is well known and takes the form of so-called structured products which are a derivative of one type of security, a basket of securities, an index, commodity price, debt issuance and / or foreign currency, or they are based on one of these categories. The properties of structured products include the following: capital protection, fixed investment duration time, rate of return based on a predetermined formula, and a built-in derivative instrument [Zaremba 2009, pp. 13-18]. In terms of these instruments, the issuer usually undertakes to make a calculated payment based on a predetermined formula at a predetermined time. Most structured products offer full protection of the capital invested at their maturity date, while others offer higher profitability rates in return for only a limited protection of capital or its lack.

Structured products in Poland take the form of bank deposits, bank securities, insurance products, investment certificates, units in foreign investment funds, bonds and a structured certificate [Bartkowiak, Echaust 2013, pp. 23-39]. They are designed to achieve a certain profile of investment value tied with the risk involved, which is made possible thanks to transactions on financial derivative instruments, such as options on interest rates and currencies [Commission of the European Communities 2009, p. 4].

Under such a classification, the social impact bond appears to be a type of debt instrument that entitles its holder to a return payment of capital and due interest on fulfilling specified conditions. Hence from the financial point of view, this type of bond is a structured product with no guarantee on capital return (or with a partial guarantee in the case of programmes with guarantees or subordinated debt ${ }^{1}$, but with the possibility of making extraordinary profits and regaining the resources invested on achieving certain results. The only major difference between the social impact bond and a standard structured product appears to be the typically positive attitude of the contractor who believes in the success of the social project resulting in the payment of resources by the public side. In other words, if the social impact bond

${ }^{1}$ An example of this type of bonds are those issued in 2012 with a view to conducting a penitentiary intervention at Rikers Island Prison, New York City. 75\% of the funds were provided by Bloomberg Philanthropies, and they were a guarantee of the return of the remaining part of the debt which was incurred on a commercial basis [Griffiths, Meinicke 2014, p. 29]. 
mechanism is constructed in a proper way, all parties of the contract are interested in the success of the project. As regards a standard structured product, its issuer does not really care if he or she will have to pay the investor any gains or not as the whole "structure" of the instrument is designed to always provide the issuer with gains, no matter if the benchmark level has been obtained or not.

To sum up, the social impact bond is characterised by the features of both debt instruments and derivative instruments. Hence, it can be called a structured product that secures the investor with:

- potential profit - i.e. the possibility of making above-average earnings, but at the risk of losing all or part of the capital invested,

- enhancing the image of institutional investors, and fulfilling the charitable ambitions of individual investors.

It is also worth noting that, on achieving success, the resources behind the social impact bond, as a vehicle used to finance social interventions, can be used repeatedly. An advantage for the public side is the fact that it is private investors who pre-finance the project, and payment is made only on achieving a result, and - importantly - ex post. Then, as regards the private investor interested in charity work, the social impact bond gives, apart from the possible above-average income, satisfaction derived from supporting pro-social initiatives and investing resources in a sensible, innovative way.

\section{The social impact bond as a financial instrument - the legal approach}

In order to decide whether social impact bonds can be issued in Poland, Polish legislation must be analysed. As pointed out before, in Polish legislation the social impact bond has not been named or defined yet. Hence some of the laws already in force must be applied if the mechanism is to be implemented successfully. However before the Polish legislation is presented, it is worth looking at the practices of the issuance of social impact bonds in other countries.

Without doubt, the social impact bond is indeed a financial instrument, but it is difficult to classify it within the currently defined types of instruments. For instance, in the USA social impact bonds can fall under the categories of investment contract, communal securities or "non-profit" instruments. The present legislation is considered insufficient in terms of the security of investors. In order to develop the market for these instruments and promote the concept of the social impact bond mechanism, a number of corresponding legal regulations should be implemented [Humphries 2014, p. 452].

Similar problems occur in the European Union. On the one hand, the EU authorities lend their support to the formula of the social impact bond mechanism as it is in line with the Lisbon Strategy, but on the other they point to the lack of transparency in terms of legal regulations which could be preclusive of the development of the market for such instruments. Apart from the need to implement appropriate laws regulating the issuance and trading in social impact bonds, EU experts also stress 
the need to offer tax exemptions to investors [Davies 2014, p. 7]. In the United Kingdom a solution like this was introduced in 2014. Under its provisions those who invest their resources in social interventions can enjoy tax relief [HM Revenue and Customs 2014].

An overview of the various studies dealing with the legal regulations on social impact bonds, the press coverage, and also the materials describing particular projects shows that the social impact bond is not subject to any separate legislation in any country in the world. The reason for this could be the newness of this formula as well as the private character of raising funds from investors. As past experience shows, social impact bonds are usually targeted at and offered to institutional investors, including philanthropic investors, usually a small, closed group of entities. If there were any instances of an open offer, they were often conditional on purchasing a certain minimal amount of values and/ or on the affluence and professionalism of the investors applying. Another solution consisted in offering bonds to retail investors through consultancy companies. Such measures result from the fact that in most countries an offer to purchase financial instruments by retail investors would require meeting the conditions imposed by the regulated and public markets. Meeting such requirements would also involve extra costs, e.g. preparing a prospectus. Moreover, the security of the investors might not be fully guaranteed due to the complexity of the instrument's construction and the fact that an inexperienced investor might not fully understand all of its provisions. On the one hand, investors do realize the social aspect of the bond, and that fact that they could simply donate their funds, but on the other, they perceive the social impact bond as a form of investment and are fully aware of its complexity as it is a non-liquid product, with small issuance rates and lacking in credit rating [Tomkinson 2013].

Whether social impact bonds can be issued in Poland on the basis of the existing Polish legislation depends on the following:

- are social impact bonds actually financial instruments, and if so - what type of instruments,

- if the social impact bond is a bond under the provisions of the Act on bonds, what type of bond is it,

- can the social impact bond be considered a structured product,

- what type of markets can and should social impact bonds be traded in,

- who or what institutions can potentially issue and purchase social impact bonds? In Polish legislation, the social impact bond can be considered a financial instrument under the provisions of two acts: the Act on Accountancy and the Act on Trading in Financial Instruments. Under the former, social impact bonds meet the criteria of financial instruments as they are a "contract through which one of the parties acquires financial assets, and the other party acquires a financial liability or a capital instrument, with the proviso that the contract, concluded by two or more parties, ensues economic results, no matter if the execution of the rights arising from the contract is unconditional or conditional" [Act of 29 September 1994, art. 3, section 1, point 23]. 
Furthermore, the Act on Trading in Financial Instruments (implementing the Markets in Financial Instruments Directive) does not define the social impact bond in a direct way, but enumerates those financial instruments that share the same features with social impact bonds listed in the previous paragraph. In particular, under the Act, financial instruments include the following [Act of 29 July 2005, art. 2, section 1, and art. 3, section 1]:

- securities, including bonds and "other tradable securities incorporating property law corresponding to the rights acquired [...] by incurring a debt, issued under the provisions of Polish or foreign legislation,"

- options - with a specifically indicated underlying instrument, but also "any other types of derivative instruments referring to assets, rights, liabilities, indices and other indicators which have the properties of derivative financial instruments."

The social impact bond, as a new financial instrument, is embraced by the two aforementioned acts. However, as those instruments will be implemented in Poland from 2018, it is strongly advised that they are sanctioned in the Polish legislation, especially by those laws that cover trading in financial instruments.

Another important issue is whether the social impact bond can be considered a bond. "A bond is a security issued in a series, in which the issuer states that they are the debtor of the bond's owner and undertakes to deliver a particular benefit" [Act of 15 January 2015, art. 4].

As suggested by its name, the social impact bond should indeed be a bond, but due to the conditional character of the undertaking (of the commissioner unto the intermediary [the issuer], and through that, of the intermediary [the issuer] onto the investor) it is not quite that obvious.

For a social impact bond to assume the form of a bond, it would have to be a revenue bond. Under article 24 of the Act of 15 January 2015 on bonds, "the issuer can issue bonds entitling the bond holder to settling the claims with a priority over the issuer's other creditors:

1. from the whole or a part of revenue, or from the whole or part of the assets of the projects which are financed in full or in part from the resources obtained from the issuance of the bonds, or

2. from the whole or a part of revenue of other projects defined by the issuer hereinafter referred to as 'revenue bonds'.

The issuer can reduce their liability for the undertakings ensuing from revenue bonds to the amount of revenue or the assets of the project, to which bond holders are entitled [...]."

Applying the abovementioned provision, it appears that the issuer (the intermediary in the social impact bonds mechanism) could issue revenue bonds serving as the funds needed to complete the intervention. At the same time this would guarantee a priority in settling the benefits of bond holders from the revenue, which, in this case, would be the "payment for results", as pledged by the commissioner. Obviously, the payment would be conditional. Priority to the whole of the payment 
or its part would belong to the investor, but at the same time it would constitute the only "guarantee" - the issuer could reduce their liability to the maximum amount of the payment.

It is worth adding that under Polish legislation it is possible that revenue bonds are issued by specified private limited companies. "The issuers of revenue bonds can be: [...] joint-stock companies or private limited companies, with their main task being the completion of a public utility project under a contract concluded with the State Treasury, a local government unit, or a group of those units, with the proviso that the contract covers the bond's maturity" [Act of 15 January 2015, art. 25, section 1, point 5]. According to this provision, an issuance could be launched by a special purpose vehicle. The only issue that could not be overseen would be bond redemption before the expiry date of the contract concluded with the commissioner. The contract concluded between intermediary and issuer, securing "payment for results", ought to provide for a payment of cash (the issuer's revenue) before its expiration. In other words, the contract ought to expire following project clearance - i.e. after the issuer redeems, or not, the bonds.

As pointed out before, the social impact bond can assume the form of a structured product. However, under the actual conditions in Poland, such an idea is rather unlikely. First, in Poland most structured products are structured bank deposits. It is unlikely for any bank to accept a formula in which the bank could refuse to pay back the resources invested by its clients as it would undermine the bank's position as a public trust institution. Furthermore, under Polish conditions, banks are not institutions established to act as intermediaries under the mechanism of social impact bonds. Second, even if the social impact bond could assume the form of a structured bond or a structured insurance product, there are no such provisions under which it would be possible to default on paying back the whole amount of the capital invested. If there does exist a limitation in capital protection, it is relatively insignificant (e.g. protection of $80 \%$ of capital). At the same time, it is still possible to make above-average earnings. All in all, the expected rates of return still remain in the black. Therefore, in light of the existing legislation, it would be most legitimate to issue social impact bonds as revenue bonds. Under such a solution, the issuer provides the investors with a priority in settling their claims from revenue, at the same time limiting their liability towards the bond holder to, at most, the value of the revenues.

Moreover, under Polish legislation, taking account of the organisation of the market and the legal regulations, the social impact bonds issued so far would be characteristic of the private market rather than the public one - in the sense of the Act on public offering and the conditions for launching financial instruments on the market and on public companies [Act of 29 July 2005, art. 3, point 1]. Certainly, an advantage offered by the private market is the possibility to design contracts in an easier and more flexible way - the contract and its conditions are negotiated by the parties. The private market also means no obligation to provide information 
as in the case of regulated markets. Another feature of the private market is that, typically, the issuer colligates with a certain group of investors (the "buy and hold" strategy), whereby secondary trading in this type of instruments does not occur. However, this must not be considered a disadvantage for it is one of the natural features of the social impact bond. In turn, the regulated market would imply stricter information and reporting requirements, and more transparency, all of which appears to be a potential impediment in terms of such a complex instrument as the social impact bond. Naturally a positive aspect is the marketing effect - issuing bonds on a regulated market creates a lot of interest among the market players and beyond. However, it seems that the promotional effect is not indispensable as far as the social impact bond is concerned, and the additional information and reporting requirements would make the complex legal-financial framework even more complicated. Bearing in mind the above considerations, at present the optimal area for launching social impact bonds is the private market. However, considering future developments, it is advisable to start work on designing appropriate regulations under which individual investors could enter the market of the SIB, as a result, the volume of capital needed to finance social interventions could be significantly increased.

The final issue to be considered is the persons of the issuer and the investor. If we applied the regulations concerning the issuance of revenue bonds, the issuers would be the previously mentioned capital companies. However, they ought to be companies with private, rather than public, capital. This ensues from the very essence of the social impact bond as a mechanism serving to realize public tasks with private resources in a more efficient and effective way than by public institutions established for this purpose.

Analogously, according to the concept of the social impact bond, it is advisable that investors are private entities. A key issue is the motives behind the investments. Social impact bonds are meant to provide measureable financial gains, but it is a social investment in the first place. An extra incentive to purchase social impact bonds is the indirect effect of applying this instrument in the form of potential benefits in the future. For instance, the investor can put their capital in projects to improve safety in the area of their operations (e.g. fighting homelessness, crime, etc.), in this way reducing their spending on security. Another example is a businessperson searching for new employees. He or she can invest resources in a mechanism that enhances employment in the area. Thus, by offering employment to the unemployed, the investor becomes a co-contractor of the project.

To conclude the subject of legal issues, it is advisable that new regulations on the social impact bond are implemented as soon as possible. This is essential in the face of the upcoming first issuances which will set new directions in financing public interventions in Poland. Appropriate regulations could open the market to new investors, provide safety of issuance and trading, and promote the concept of social impact bonds. The above conducted overview of the Polish legislation shows 
that the lack of new regulations does not mean that social impact bonds cannot be issued in Poland. Issuance would be still possible with social impact bonds taking the form of revenue bonds. There is also a possibility that the mechanisms of the social impact bond in Poland, in terms of their organisational and the financial aspects, are designed as civil law contracts under the freedom of contract [Act of 23 April 1964 - the Civil Code, art. 353].

\section{Conclusions}

The concept of the social impact bond mechanism falls into contemporary trends of public management which are targeted at increasing the effectiveness in realizing public interventions and involving private investors in their implementation. Until now, the projects under the formula in question have depended on funds raised from investors under the terms of civil law contracts. According to the provisions of those contracts, the issuer undertakes to pay back the obtained capital along with capital gains in the case of obtaining the desired social target which is paid for by the public side, i.e. the commissioner. The increasingly popular way of financing projects with social impact bonds requires putting a number of due regulations in place to smooth the issuance of and trading in this type of values.

As shown in this paper, social impact bonds share the features of both debt instruments (bonds) and derivative instruments, and options in particular. These instruments are covered by the financial legal regulations of particular countries, but their hybrid form as the social impact bond is not. The existing solutions have restricted the issuance of social impact bonds to the private market only. However, it appears that individual investors too would show a lot of interest in this type of investment as shown by the example of developed countries, the Anglo-Saxon ones in particular. To provide retail investors with access to that market it is indispensable to give a formal structure to the mechanisms of issuance of and trading in the instruments in question. It seems that the only threat could be the increased costs of such a form of financing as it would be necessary to meet the requirements of the regulated market. However, this drawback could be set off against the increased demand for these instruments on the part of private investors.

Poland, too, needs new regulations as 2018 will see the first social interventions carried out under the formula in question. They are the winning projects of a contest by the Ministry of Development and Finance, co-financed from the European Social Fund. The existing regulations seem sufficient to allow an issuance of social impact bonds in the private market. However, if the authorities aim to popularise this form of financing public tasks and allow individual investors to purchase this type of instruments, putting new regulations in place seems indispensable. An extra incentive could also be offering tax exemptions to those investing in social interventions, as practised in the United Kingdom. 


\section{Bibliography}

Act of 15 January 2015 on bonds, Journal of Laws 2017, items 1089, 1199.

Act of 23 April 1964 - Civil Code, Journal of Laws 2017, item 459.

Act of 29 July 2005 on trading in financial instruments, Journal of Laws 2017, item 1768.

Acts of 29 July 2005 on public offering and the conditions of introducing financial instruments in the organised system of trading, and public companies, Journal of Laws 2016, item 1639.

Act of 29 September 1994 on accountancy, Journal of Laws 2016, item 1047.

Aylott A., Bo'sher L., Mulgan G., Reeder N., 2011, Social Impact Investment: The Challenge and Opportunity of Social Impact Bonds, The Young Foundation.

Bartkowiak M., Echaust K., 2013, Produkty strukturyzowane - konstrukcja, wycena, aspekty prawne, CeDeWu, Warszawa.

Cooper Ch., Graham C., Himick D., 2016, Social impact bonds: The securitization of the homeless, Accounting, Organizations and Society, No. 55, pp. 63-82.

Costa K., Shah S., Ungar S., 2012, Frequently Asked Questions: Social Impact Bonds, Center for American Progress.

Czarnecki K., 2011, Idee i praktyki Nowego Zarządzania Publicznego, Zarządzanie Publiczne, nr 1(15), pp. 5-19.

Davies R., 2014, Social impact bonds. Private finance that generates social returns, European Parliamentary Research Service, PE 538.223.

Department for International Development, 2014, Sharpening Incentives to Perform: DFID's Strategy for Payment for Results, London.

Department of Health, 2012, A simple guide to payment for results, Payments by Results Team. National Health Service, London.

Dębski W., 2007, Rynek finansowy i jego mechanizmy, Wydawnictwo Naukowe PWN, Warszawa.

Eggers W.D., Macmillan P., 2014, Rewolucja rozwiązań. Wspótpraca pomiędzy biznesem, rządami oraz przedsiębiorstwami społecznymi na rzecz rozwiązania największych problemów wspótczesnego świata, Deloitte, Poltext, Warszawa.

Griffiths A., Meinicke Ch., 2014, Introduction to Social Impact Bonds and Early Intervention, Early Intervention Foundation.

HM Revenue and Customs, 2014, Social Investments Tax Relief (SITR).

Humphries K.W., 2014, Not Your Older Brother's Bonds: The Use and Regulation of Social-Impact Bonds in the United States, Law and Contemporary Problems, Vol. 76, pp. 433-452.

Instiglio, 2017, Impact Bonds Worldwide, http:/www.instiglio.org/en/sibs-worldwide.

Jajuga K., Jajuga T., 2011, Inwestycje - instrumenty finansowe, aktywa finansowe, ryzyko finansowe, inżynieria finansowa, Wydawnictwo Naukowe PWN, Warszawa.

Komisja Wspólnot Europejskich, 2009, Komunikat Komisji do Parlamentu Europejskiego i Rady w sprawie detalicznych produktów inwestycyjnych w pakietach, $\mathrm{KOM}(2009) 204$.

Larsson N., 2016, Does payment for results dehumanise aid work or encourage success?, The Guardian, https:/www.theguardian.com/global-development-professionals-network/2016/apr/25/payment-by-results-dehumanise-aid-work-encourage-success.

Marchewka-Bartkowiak K., 2014, Nowe zarządzanie publiczne, Infos, no. 18(178).

Marchewka-Bartkowiak K., Wiśniewski M., 2015, Obligacje społeczne - nowy instrument finansowania zadań społecznych, Studia Biura Analiz Sejmowych, no. 4(44), pp. 205-222.

Ministerstwo Rozwoju, 2016, Obligacje społeczne jako narzędzie zwiększenia efektywności świadczenia ustug społecznych w obszarach wsparcia EFS. Założenia konkursu, https://www.mr.gov.pl/ media/20758/Obligacje_spoleczne_zalozeniakonkursu_MR.pdf.

O'Connor R.J., Neumann V.C., 2006, Payment for results or payment by outcome? The history of measuring medicine, Journal of the Royal Society of Medicine, no 99(5), pp. 226-231. 
PWC, PriceWaterhouseCoopers, 2014, Getting what you pay for: Payment-by-results in international development, http://www.pwc.co.uk/government-public-sector/assets/getting-what-you-pay-forpayment-by-results-in-international-development.pdf.

Rajca L., 2009, Koncepcja New Public Management a reformy samorzadu terytorialnego wybranych państw Europy Zachodniej, Studia Regionalne i Lokalne, nr 2(36), pp. 72-87.

Tomkinson E., 2013, Social Impact Bonds (SIBS): Who are the investors?, www.emmatomkinson.com. Zaremba A., 2009, Produkty strukturyzowane - inwestycje naszych czasów, Helion, Gliwice.

Zawicki M., 2007, Instrumenty nowego zarzadzania publicznego, Zeszyty Naukowe Uniwersytetu Ekonomicznego w Krakowie, nr 759, pp. 141-172.

\section{OBLIGACJA SPOEECZNA JAKO INSTRUMENT FINANSOWY}

Streszczenie: Obligacje społeczne stanowią innowacyjny mechanizm finansowania zadań społecznych za pomocą środków finansowych prywatnych inwestorów. Zwrot zainwestowanych kapitałów oraz dochodów kapitałowych uzależniony jest od uzyskania założonego z góry celu społecznego, za który płaci strona publiczna w formule ,płatności za rezultaty”. W dotychczasowych opracowaniach na temat tego mechanizmu koncentrowano się przede wszystkim na jego wymiarze zadaniowym i organizacyjnym. Celem niniejszego opracowania jest próba zdefiniowania obligacji społecznej jako instrumentu finansowego. Oprócz wskazania pokrótce jego istoty przeprowadzono rozważania na temat finansowej strony mechanizmu. Po pierwsze, podjęto próbę określenia miejsca obligacji społecznej w klasyfikacjach teoretycznych instrumentów finansowych. Po drugie, wskazano na miejsce tego instrumentu w systemie prawa finansowego. Rozważania kończą wnioski dotyczące potrzeby uregulowania nowego instrumentu w polskim prawodawstwie.

Słowa kluczowe: obligacje społeczne, instrumenty finansowe, obligacje, zarządzanie publiczne. 